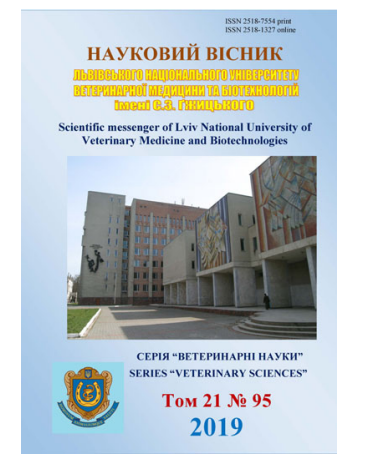

Науковий вісник Дьвівського національного університету ветеринарної медицини та біотехнологій імені С.3. Гжицького. Серія: Ветеринарні науки

Scientific Messenger of Lviv National University of Veterinary Medicine and Biotechnologies. Series: Veterinary sciences

\title{
Correction the blood biochemical parameters in transition dairy cows by hop cones and vitamin $E$ supplement
}

\author{
I. Vudmaska ${ }^{1}$, S. Sachko ${ }^{1}$, A. Petruk ${ }^{2}$, N. Pakholkiv ${ }^{1}$, V. Hudyma ${ }^{1}$, A. Skorokhid ${ }^{1}$ \\ ${ }^{1}$ Institute of Animal Biology, Lviv, Ukraine \\ ${ }^{2}$ Stepan Gzhytskyj National University of Veterinary Medicine and Biotechnologies, Lviv, Ukraine
}

\section{Article info}

Received 19.09.2019 Received in revised form 21.10.2019 Accepted 22.10.2019

Institute of Animal Biology, V. Stus Str., 38, Lviv, 79034, Ukraine

Tel.: +380-322-60-07-95

E-mail:talokha@gmail.com

Stepan Gzhytskyi National University of Veterinary Medicine and Biotechnologies Lviv, Pekarska Str., 50, Lviv, 79010, Ukraine.
Vudmaska, I., Sachko, S., Petruk, A., Pakholkiv, N., Hudyma, V., \& Skorokhid, A. (2019). Correction the blood biochemical parameters in transition dairy cows by hop cones and vitamin $e$ supplement. Scientific Messenger of Lviv National University of Veterinary Medicine and Biotechnologies. Series: Veterinary sciences, 21(95), 117-121. doi: 10.32718/nvlvet9522

In the prevention and treatment of cow ketosis, the regulation of glucose and fatty acids is the main focus, while ammonia intoxication is largely ignored. The intensity of formation of the rumen ammonia can be reduced by ionophore antibiotic monensin. Hop cones contain a number of biologically active components including phytoionophores: prenylated polyphenols lupulon, humulon and their derivatives. Therefore, hop cones can be considered as a potential substitute for antibiotics-ionophores. Vitamin E, fed to ruminants in large quantities, stimulates the cellulosolytic bacteria of the rumen. Accordingly, co-feeding cows with hops and vitamin E supplements can reduce ammonia formation without inhibition the carbohydrate fermentation in the rumen. The experiment used two groups of dry Ukrainian dairy black-and-white breed cows with productivity 6-7 thousand $\mathrm{kg}$ of milk for previous lactation, 10 animals per each group. The trial was performed during the last 3 weeks of dry period and the first 3 weeks after calving. Animals were fed a standard balanced diet containing: grass silage, corn silage, barley grain, corn grain, soybean meal, molasses, salt, mineral and vitamin premix. The first group was the control. The diet of second group was supplemented with $300 \mathrm{mg}$ of $\alpha$-tocopherol acetate (0.6 $\mathrm{g}$ of Rovimix E-50) and $1 \mathrm{~g}$ of dry hop cones per $\mathrm{kg}$ of DM. Prior to calving, the tested feed additive reduced the concentration of lipid peroxidation products $(P<0.05)$ in the blood plasma without affection other parameters. More significant changes were detected after calving. An increase in glucose concentration $(P<0.05)$, triacylglycerol $(P<0.05)$, cholesterol esters $(P<0.05)$ and a decrease in the concentration of NEFA $(P<0.05)$ were found in the blood of cows of the experimental group in a week after parturition. One month after calving, differences between control and experimental blood plasma parameters were significantly less pronounced. Therefore, addition of $300 \mathrm{mg}$ of $\alpha$-tocopherol acetate and $1 \mathrm{~g} / \mathrm{kg}$ of dry hop cones per $\mathrm{kg}$ of dry matter of the diet during the transition period stimulates liver glucose synthesis and reduces the rate of fatty acid release from adipose tissue. The specified feed additive can be used to prevent metabolic disorders in early-lactation dairy cows.

Key words: cows, hops cones, vitamin E, blood.

\section{Корекція біохімічних показників крові корів у перед- i післяотельний періоди шишками хмелю та вітаміном Е}

\author{
I.В. Вудмаска ${ }^{1}$, С.Р. Сачко ${ }^{1}$, А.П. Петрук², Н.І. Пахолків ${ }^{1}$, В.Ю. Гудима ${ }^{1}$, А.В. Скорохід ${ }^{1}$ \\ ${ }^{1}$ Інститут біології тварин НААН, м. Львів, Україна \\ ${ }^{2}$ Львівський національний університет ветеринарної медицини та біотехнологій імені С.3. Гжсицького, \\ м. Львів, Україна
}


При профілактиці та лікуванні кетозу корів основну увагу приділяють регуляції обміну глюкози та жирних кислот, тимчасом як інтоксикація аміаком переважно залишається поза увагою. Змениити інтенсивність утворення в рубці аміаку можна використанням антибіотиків-іонофорів, зокрема монензину. Шишки хмелю містять низку біологічно активних компонентів, у тому числі й речовини з іонофорною дією: пренільовані поліфеноли лупулон, хумулон та їх похідні. Отже, вони можуть розглядатись як потенційний замінник антибіотиків-іонофорів. Вітамін Е при введенні до раціону жуйних тварин у великих кількостях стимулює життєдіяльність иелюлозолітичних бактерій рубия. Відповідно спільне згодовування коровам шишок хмелю і вітаміну Е може сприяти зменшенню аміакоутворення без пригнічення ферментації вуглеводів у рубиі. Для досліду сформовано 2 групи корів української молочної чорно-рябої породи, продуктивність за попередню лактачію 6-7 тис. кг молока, 10 тварин у групі. Дослід тривав протягом останніх 3-х тижнів сухостою та периих 3-х тижнів після отелення. Тварини отримували стандартний збалансований раціон, який містив: сінаж різнотравний, силос кукурудзяний, ячмінно-кукурудзяну дерть, шрот соєвий, мелясу, сіль кормову,

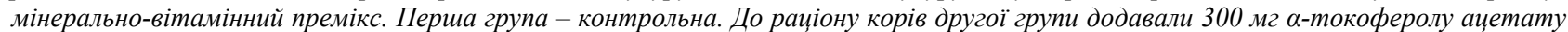
(0,6 г Ровімікс E-50) та 1 г/кг сухих шишок хмелю на кг сухої речовини рачіону. У крові корів до отелення досліджувана кормова добавка знижувала концентрацію продуктів пероксидного окиснення $(P<0,05)$, не впливаючи на інші показники. Після отелення виявлено суттєвіші зміни. У крові корів дослідної групи виявлено зростання концентрації глюкози (P < 0,05), триацилглічеролів $(P<0,05)$, ерірів холестеролу $(P<0,05)$ та зниження концентрації НЕЖК $(P<0,05)$. Через місяць після отелення різниці між показниками плазми крові контрольних і дослідних корів значною мірою нівелювались. Отже, введення до раціону корів протягом транзитного періоду 300 мг а-токоферолу ацетату та 1 г/кг сухих иишок хмелю на кг сухої речовини раціону стимулює синтез глюкози печінкою, зменшує інтенсивність вивільнення жирних кислот з жирової тканини. Вказана кормова добавка може застосовуватись для профілактики метаболічних порушень обміну речовин корів у ранній післяотельний період.

Ключові слова: корови, иишки хмелю, вітамін Е, кров.

\section{Ветуп}

Для високопродуктивних корів характерний напружений обмін речовин, що призводить до ряду метаболічних порушень, які викликають погіршення фізіологічного стану, виникнення захворювань та зниження молочної продуктивності. Особливо ці відхилення обміну речовин проявляються після отелення та у пік лактації, тобто під час гормональної перебудови та найвищого метаболічного навантаження організму (Wankhade et al., 2017). Головним чинником запобігання метаболічним захворюванням таких корів $\epsilon$ ретельне дотримання технологічних норм годівлі та утримання, проте, як свідчить досвід провідних країн 3 розвиненим молочним скотарством, цих заходів у багатьох випадках виявляється недостатньо (Vudmaska et al., 2018). Незважаючи на високий рівень технологій, сучасне тваринництво надалі зіштовхується 3 проблемами здоров'я корів, пов'язаними з порушеннями обміну речовин та викликаними ними супутніми хворобами: кетозом, ацидозом, жировим переродженням печінки, зміщенням сичуга, ламінітом, маститом, порушенням відтворювальної здатності (Opsomer, 2015). Для профілактики метаболічних порушень корів застосовують кормові добавки, які регулюють рубцеву ферментацію та метаболічні процеси у таких ключових органах, як печінка, молочна залоза та жирова тканина. Незважаючи на досить широкий асортимент таких добавок, результативність їх використання все ще недостатня, тому пошук ефективних компонентів і способів їх компонування триває надалі.

Однією 3 найважливіших метаболічних проблем високопродуктивних корів $\epsilon$ негативний енергетичний баланс у родовий період та на початку лактації, за якого у крові знижується рівень глюкози та зростає концентрація неестерифікованих жирних кислот (Wankhade et al., 2017; Vudmaska et al., 2018). Дефіцит енергії поповнюють концентрованими кормами, що призводить до надмірного утворення аміаку в рубці. Крім того, після отелення у корів знижений апетит, вони гірше поїдають грубі корми, у результаті чого зменшується утворення ацетату в рубці, що ще більше посилює негативний енергетичний баланс організму. При профілактиці та лікуванні стеатозу і кетозу основну увагу приділяють регуляції обміну глюкози та жирних кислот, тоді тимчасом інтоксикація аміаком переважно залишається поза увагою. Зменшити інтенсивність утворення в рубці аміаку можна використанням іонофорів, зокрема монензину, який вибірково діє на грам-позитивні бактерії, до яких належать основні продуценти аміаку (Khodamoradi et al., 2013; Compton et al., 2015; Markantonatos \& Varga, 2017). Оскільки останнім часом спостерігається тенденція до заборони кормових антибіотиків (Regulation, EC), важливим напрямом досліджень $є$ пошук їхніх замінників рослинного походження. Шишки хмелю містять ряд біологічно активних компонентів, у тому числі й речовини з іонофорною дією: пренільовані поліфеноли лупулон, хумулон та їхні похідні (Flythe et al., 2017). Отже, вони можуть розглядатись як потенційний замінник антибіотиків-іонофорів (United States patent 8197863 B2, 2012; Lavrenčič et al., 2018; Vudmaska et al., 2018). Крім того, у шишках хмелю наявні сполуки 3 протигрибковими, антиоксидантними, протизапальними, фітоестрогенними властивостями (Krofta et al., 2008; Karabín et al., 2016).

У рубці іонофори діють не лише на гіперпродуцентів аміаку, вони активні також, хоча й меншою мірою, щодо целюлозолітичних бактерій. Тому при введені до раціону іонофорів бажано стимулювати целюлозолітичну активність (Flythe et al., 2017). Biдомо, що вітамін Е при введенні до раціону жуйних тварин у великих кількостях, впливає на життєдіяльність бактерій рубця, зокрема на ліполітичну, біогідрогенізаційну та целюлозолітичну активність (Pottier, 2006; Politis, 2012; Wei et al., 2016). Відповідно спільне згодовування коровам шишок хмелю і вітаміну Е може сприяти зменшенню аміакоутворення, не впливаючи негативно на гідроліз клітковини корму (Khodamoradi et al., 2013).

Метою цього дослідження було встановити вплив профілактичної кормової добавки, що містить шишки хмелю та збільшену кількість вітаміну Е метаболіч- 
ний профіль крові корів протягом післяотельного періоду.

\section{Матеріал і методи досліджень}

Використано 2 групи сухостійних корів української молочної чорно-рябої породи з продуктивністю за попередню лактацію 6-7 тис. кг молока, по 10 тварин у групі.

Тварини отримували стандартний збалансований раціон, який містив: сінаж різнотравний, силос кукурудзяний, ячмінно-кукурудзяну дерть, шрот соєвий, мелясу, сіль кормову, мінерально-вітамінний премікс.

Перша група служила контролем. Коровам другої групи додавали 300 мг $\alpha$-токоферолу ацетату $(0,6$ г Ровімікс Е-50) та 1 г/кг сухих шишок хмелю на кг сухої речовини раціону. Дослід тривав протягом останніх 3-х тижнів сухостою та перших 3-х тижнів після отелення.

Для лабораторних досліджень використали венозну кров, яку брали з яремної вени перед отеленням, через тиждень та місяць після отелення. У крові визначали вміст загального білка, сечовини, загальних ліпідів, триацилгліцеролів, холестерину, глюкози за допомогою діагностичних наборів, концентрацію неестерифікованих жирних кислот, лактату згідно 3 методами викладеними у довіднику “Лабораторні методи досліджень у біології, тваринництві та ветеринарній медицині” (Vlizlo et al., 2012).

\section{Результати та їх обговорення}

За тиждень до отелення не виявлено вірогідних різниць у показниках плазми крові корів контрольної та дослідної груп. Спостерігалась лише тенденція до збільшення концентрації глюкози і зменшення концентрації сечовини.

Після отелення вплив додавання до раціону шишок хмелю і вітаміну Е проявлявся суттєвіше. Через тиждень після отелення у плазмі корів спостерігалось характерне для цього періоду зниження концентрації глюкози та зростання концентрації неестерифікованих жирних кислот. Кормова добавка значно зменшила ці несприятливі для здоро'я корів зміни. Вміст глюкози у плазмі крові тварин дослідної групи через тиждень після отелення був на 22\% більшим ніж у контрольній групі $(\mathrm{P}<0,01)$, і за кількісним показни-ком не відрізнявся від вмісту глюкози за тиждень до та через місяць після отелення.

\section{Таблиця}

Біохімічні показники плазми крові, ммоль/л $(\mathrm{M} \pm \mathrm{m}, \mathrm{n}=5)$

\begin{tabular}{|c|c|c|}
\hline \multirow{2}{*}{ Показники } & \multicolumn{2}{|c|}{ Групи тварин } \\
\hline & Контроль & Хміль+вітамін Е \\
\hline & \multicolumn{2}{|c|}{ до отелення } \\
\hline Загальний білок, г/л & $73,14 \pm 4,95$ & $72,33 \pm 5,18$ \\
\hline Глюкоза & $3,07 \pm 0,05$ & $3,17 \pm 0,06$ \\
\hline Сечовина & $6,10 \pm 0,42$ & $5,80 \pm 0,48$ \\
\hline Триацилгліцероли & $0,19 \pm 0,02$ & $0,20 \pm 0,03$ \\
\hline НЕЖК & $0,40 \pm 0,02$ & $0,42 \pm 0,03$ \\
\hline Загальний холестерол & $4,07 \pm 0,29$ & $4,20 \pm 0,23$ \\
\hline Вільний холестерол & $1,51 \pm 0,16$ & $1,59 \pm 0,12$ \\
\hline Естерифікований холестерол & $2,55 \pm 0,33$ & $2,61 \pm 0,11$ \\
\hline \multirow[t]{2}{*}{ Лактат } & $0,61 \pm 0,11$ & $0,53 \pm 0,09$ \\
\hline & тиждень після & отелення \\
\hline Загальний білок, г/л & $67,22 \pm 4,14$ & $75,14 \pm 2,01$ \\
\hline Глюкоза & $2,31 \pm 0,04$ & $2,82 \pm 0,11 * *$ \\
\hline Сечовина & $6,78 \pm 0,48$ & $6,83 \pm 0,40$ \\
\hline Триацилгліцероли & $0,20 \pm 0,03$ & $0,30 \pm 0,03 *$ \\
\hline НЕЖК & $0,91 \pm 0,07$ & $0,71 \pm 0,12 *$ \\
\hline Загальний холестерол & $3,92 \pm 0,17$ & $4,20 \pm 0,14$ \\
\hline Вільний холестерол & $1,51 \pm 0,16$ & $1,49 \pm 0,12$ \\
\hline Естерифікований холестерол & $2,40 \pm 0,03$ & $2,71 \pm 0,10^{*}$ \\
\hline \multirow[t]{2}{*}{ Лактат } & $0,81 \pm 0,14$ & $0,60 \pm 0,06^{*}$ \\
\hline & місяць після & отелення \\
\hline Загальний білок, г/л & $70,25 \pm 1,48$ & $69,32 \pm 3,71$ \\
\hline Глюкоза & $2,95 \pm 0,11$ & $3,11 \pm 0,06$ \\
\hline Сечовина & $5,69 \pm 0,37$ & $5,53 \pm 0,39$ \\
\hline Триацилгліцероли & $0,25 \pm 0,03$ & $0,27 \pm 0,03$ \\
\hline НЕЖК & $0,61 \pm 0,09$ & $0,45 \pm 0,05^{*}$ \\
\hline Загальний холестерол & $3,82 \pm 0,12$ & $4,12 \pm 0,14$ \\
\hline Вільний холестерол & $1,24 \pm 0,06$ & $1,21 \pm 0,07$ \\
\hline Естерифікований холестерол & $2,58 \pm 0,05$ & $2,90 \pm 0,14^{*}$ \\
\hline Лактат & $0,75 \pm 0,06$ & $0,58 \pm 0,04^{*}$ \\
\hline
\end{tabular}


Через тиждень після отелення у плазмі крові корів концентрація неестерифікованих жирних кислот підвищилась більш ніж удвічі порівняно з сухостійним періодом. Комбіноване застосування шишок хмелю і вітаміну Е сприяло зниженню вмісту НЕЖК на 21\% $(\mathrm{P}<0,05)$. Хоча концентрація НЕЖК у крові корів через тиждень після отелення надалі залишалась досить високою, проте отриманий ефект достатньо суттєвий для нормалізації метаболічного стану організму. Зменшення концентрації НЕЖК плазми крові під впливом кормової добавки зберігалось і через місяць після отелення. У цей період вміст неестерифікованих жирних кислот у крові корів контрольної і дослідної груп становив відповідно 0,61 та 0,45 ммоль/л, тобто концентрація НЕЖК у крові корів дослідно групи повністю нормалізувалась до рівня сухостійних корів.

За дії кормової добавки до раціону шишок хмелю та вітаміну Е у плазмі крові зростала кількість триацилгіцеролів, особливо суттєво цей вплив проявився через тиждень після отелення, коли концентрація триацилгіцеролів у плазмі крові тварин дослідної групи в 1,5 разу перевищувала показник корів контрольної групи $(\mathrm{P}<0,05)$.

Додавання до раціону шишок хмелю і вітаміну Е впливало на обмін холестеролу, збільшуючи вміст естерифікованої його форми у плазмі крові. Цей ефект спостерігався лише після отелення як через тиждень, так і через місяць після нього. Зокрема, через тиждень після отелення вміст ефірів холестеролу у плазмі крові корів дослідної групи перевищував показник контрольної групи на $13 \%$ ( $<0,05)$, а через місяць - на $12 \%(\mathrm{P}<0,05)$. Оскільки зростання у плазмі крові вмісту ефірів холестеролу зростало одночасно зі зростанням вмісту триацилгіцеролів, це, найімовірніше, свідчить про збільшення у ній кількості ліпопротеїнів дуже низької щільності, для яких характерний такий ліпідний склад. Зростання у крові вмісту триацилгліцеролів на тлі зменшення вмісту неестерифікованих жирних кислот свідчить про поліпшення обміну речовин і зменшення схильності корів дослідної групи до метаболічних порушень, зокрема до жирового переродження печінки.

Використання кормової добавки помірно збільшило вміст жиру та протеїну у молоці корів дослідної групи. Варто зазначити, що іонофори та вітамін Е порізному впливають на жирність молока. Згідно з нашими попередніми дослідженнями та літературних даних монензин супліддя хмелю знижують вміст жиру в молоці, а вітамін $\mathrm{E}$ - навпаки, підвищує його. У цьому досліді за сумісного використання шишок хмелю і вітаміну Е жирність молока була дещо більшою, ніж у контролі, отже вітамін Е компенсував жирдепресуючу дію іонофорів хмелю.

Добовий надій корів дослідної групи збільшився на 4,5\% порівняно з надоєм корів контрольної групи. Внаслідок дещо вищої жирності молока надій на базисну жирність зріс на 6,4\%. Наявна тенденція до збільшення виходу молочного жиру та протеїну.

\section{Висновки}

1. Введення до раціону корів протягом транзитного періоду токоферолу ацетату та шишок хмелю стимулює синтез глюкози печінкою та зменшує інтенсивність вивільнення жирних кислот з жирової тканини.

2. Комплексне використання вітаміну Е та шишок хмелю запобігає негативному впливу іонофорних сполук хмелю на жирність молока корів, що пов'язано 3 взаємно компенсуючою дією поліфенольних сполук хмелю і токоферолу на целюлозолітичні бактерії рубця.

3. Вказана кормова добавка може застосовуватись для профілактики метаболічних порушень обміну речовин корів у післяотельний період.

\section{References}

Compton, C.W., Young, L., \& McDougall, S. (2015). Efficacy of controlled-release capsules containing monensin for the prevention of subclinical ketosis in pasture-fed dairy cows. N Z Vet J., 63(5), 249-253. doi: 10.1080/00480169.2014.999842.

Flythe, M.D. Flythe, M.D., Kagan, I.A., Wang, Y., \& Narvaez, N. (2017). Hops (Humulus lupulus L.) Bitter acids: modulation of rumen fermentation and potential as an alternative growth promoter. Front. Vet. Sci., 4, 131. doi: 10.3389/fvets.2017.00131.

Karabín, M., Hudcová, T., Jelínek, L., \& Dostálek, P. (2016). Biologically active compounds from hops and prospects for their use. Comprehensive Reviews in Food Science and Food Safety, 15, 542-567. doi: 10.1111/1541-4337.12201.

Khodamoradi, Sh., Fatahnia, F., Taherpour, K., Pirani, V., Rashidi, L., \& Azarfar, A. (2013). Effect of monensin and vitamin $\mathrm{E}$ on milk production and composition of lactating dairy cows. J Anim Physiol Anim Nutr (Berl), 97(4), 666-674. doi: 10.1111/j.14390396.2012.01307.x.

Krofta, K., Mikyška, A., \& Hašková, D. (2008). Antioxidant characteristics of hops and hop products. J. Inst. Brew, 114(2), 160-166. doi: 10.1002/j.20500416.2008.tb00321.x.

Lavrenčič, A., Pirman, T., \& Žgur, S. (2018). Use of hop cones in growing beef cattle nutrition. Annals of Warsaw University of Life Sciences - SGGWAnimal Science, 57(2), 121-131. doi: 10.22630/AAS.2018.57.2.12.

Markantonatos, X., \& Varga, G.A. (2017). Effects of monensin on glucose metabolism in transition dairy cows. J Dairy Sci., 100(11), 9020-9035. doi: $10.3168 /$ jds.2016-12007.

Opsomer, G. (2015). Interaction between metabolic challenges and productivity in high yielding dairy cows. Jpn J Vet Res., 63(1), 1-14. http://hdl.handle.net/2115/57935.

Overton, T.R., McArt. J.A.A., Nydam, D.V. (2017). A 100-Year Review: Metabolic health indicators and management of dairy cattle. J Dairy Sci., 100(12), 10398-10417. https://www.ncbi.nlm.nih.gov/pubmed/ 29153172. 
Politis, I. (2012). Reevaluation of vitamin E supplementation of dairy cows: bioavailability, animal health and milk quality. Animal., 6(9), 1427-1434. doi: $10.1017 / \mathrm{S} 1751731112000225$.

Pottier, J. (2006). Effect of dietary vitamin E on rumen biohydrogenation pathways and milk fat depression in dairy cows fed high-fat diets. J of Dairy Sci., 89(2), 685-692. doi: 10.3168/jds.S0022-0302(06)72131-2.

Regulation (EC) No 1831/2003 of the European Parliament and the Council of 22 September 2003 on Additives for Use in Animal Nutrition L268/236. OJEU, 2003.

United States patent 8197863 B2 (2012). Hop acids as a replacement for antibiotics in animal feed. 2012 Jun 12.

Vlizlo, V.V., Fedoruk, R.S., Ratych, I.B. i in. (2012). Laboratorni metody doslidzhen u biolohii, tvarynnytstvi ta veterynarnii medytsyni. Dovidnyk. Lviv:
SPOLOM, 355-368.

Vudmaska, I., Petruk, A., Vaskiv, R., \& Vlizlo, V. (2018). Comparison of monensin and hop cones effects on rumen fermentation and blood parameters in transition dairy cows. Hungarian Veterinary Journal, 140(1), 299-304.

Wankhade, P.R., Manimaran, A., Kumaresan, A., Jeyakumar, S., Ramesha, K.P., Sejian, V., Rajendran, D., \& Varghese, M.R. (2017). Metabolic and immunological changes in transition dairy cows: A review. Vet World, 10(11), 1367-1377. doi: 10.14202/vetworld.2017.13671377.

Wei, C., Lin, S., Wu, J., Zhao, G., Zhang, T., \& Zheng, W. (2016). Supplementing vitamin E to the ration of beef cattle increased the utilization efficiency of dietary nitrogen. Asian-Australasian J of Animal Sci, 9(3), 372-377. doi: 10.5713/ajas.15.0322. 